\title{
Characterisation of Eubacterium cell wall: peptidoglycan structure determines arthritogenicity
}

\author{
X Zhang, M Rimpiläinen, E Šimelyte, P Toivanen
}

\begin{abstract}
Objective-To elucidate factors involved in the arthritogenicity of bacterial cell walls.

Methods-For characterisation of an arthritogenic Eubacterium aerofaciens cell wall, peptidoglycan-polysaccharide (PGPS) polymers were isolated by removing cell wall associated proteins (CWPs), PG and PS moieties were separated, and an attempt was made to de- $\mathrm{O}$-acetylate PGPS. The cell wall of $E$ limosum was used as a non-arthritogenic control. The chemical composition of these cell wall preparations was analysed by gas chromatography-mass spectrometry. Also, their ability to resist lysozyme degradation and to sustain experimental chronic arthritis was tested.

Results-The observations made with the cell wall of $E$ aerofaciens, an anaerobic habitant of the human intestine, were compared with those reported from a pathogenic Streptococcus, showing that in both strains a complex consisting of PG-PS is required for the induction of chronic arthritis. The PS moiety most probably protects $P G$ from enzyme degradation, allowing prolonged tissue persistence and leading to the chronic synovial inflammation. CWPs attached to PG-PS are not necessary for this function. $O$-Acetylation of PG, which is required for arthritogenicity of the streptococcal cell
\end{abstract}

Turku Immunology Centre, Department of Medical Microbiology,

Turku University, Turku, Finland X Zhang

M Rimpiläinen

E Šimelyte

P Toivanen

Correspondence to: Dr X Zhang, Department of Medical Microbiology, Turku University, Kiinamyllynkatu 13, FIN-20520 Turku,

Finland

xzhang@utu.

Accepted 1 August 2000

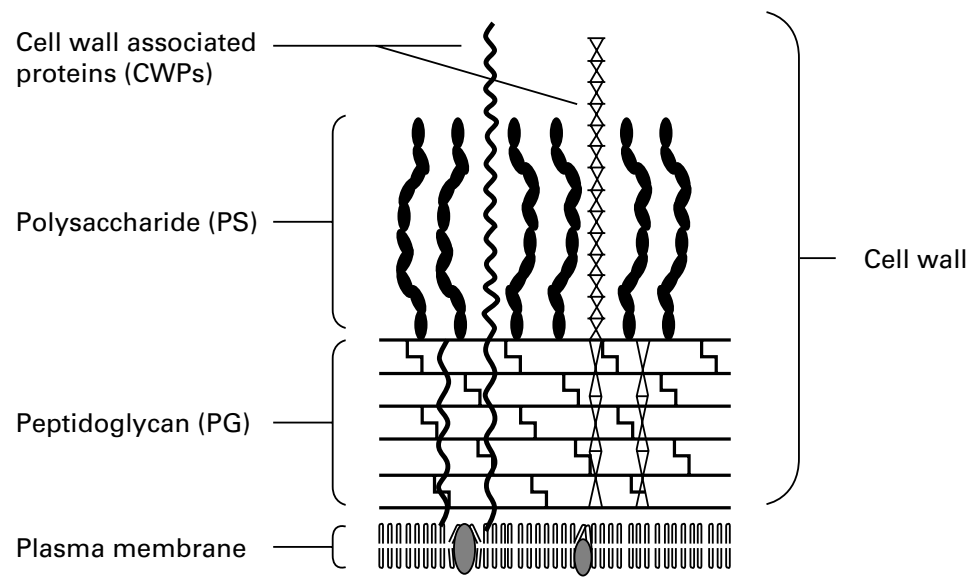

Figure 1 Gram positive bacterial cell wall contains mainly peptidoglycan (PG), polysaccharide (PS), and cell wall associated proteins (CWPS). The CWPs outside the PS and $P G$ layers can be removed by proteolytic enzymes, whereas the proteins inside the $P G$ layer are difficult to remove without breaking the PG structure. PS binds covalently to the $P G$ layer, and protects $P G$ polymers from the degrading enzymes. PG consists of several layers (up to 70) of sugar chains composed of $N$-acetylglucosamine and $N$-acetylmuramic acid alternately linked each other. Short peptides bound to the $N$-acetylmuramic acid (muramyl peptides) connect the sugar chains. PG and the muramyl peptides possess multiple biological activities. wall, seems not to be present in the arthritogenic $E$ aerofaciens PG or only occurs to a small degree; attempts to de-O-acylate the $E$ aerofaciens cell wall did not affect its arthritogenicity or lysozyme resistance. Conclusion-The results obtained indicate that the source of bacterial cell wall plays no part in the chemical or structural requirements for PG to induce chronic cell wall arthritis in the rats; the chemical structure of the PG moiety is decisive.

(Ann Rheum Dis 2001;60:269-274)

The intestinal flora of patients with newly developed rheumatoid arthritis (RA) is significantly different from that of non-RA controls. $^{1}{ }^{2}$ This difference is primarily due to anaerobic bacterial species-namely, to Eubacterium aerofaciens. ${ }^{1}$ On the other hand, a single intraperitoneal (IP) injection of cell walls isolated from this Gram positive bacterium, a normal habitant of the human gut, induces a chronic arthritis in Lewis rats, whereas cell walls from a related $E$ limosum are nonarthritogenic. $^{34}$

The Gram positive bacterial cell wall skeleton mainly contains peptidoglycan (PG), polysaccharide (PS), and the cell wall associated proteins (CWPs) (fig 1). The CWPs in the Gram positive cell wall extend from the plasma membrane through the PG and PS layers to the cell surface and are covalently attached to the PG. ${ }^{56}$ They interact with the extracellular environment and contribute to the development of bacterial infections. CWPs of Staphylococcus aureus interact with specific host molecules either by promoting attachment to the host tissues or by preventing the phagocytic clearance. ${ }^{7}$ CWPs of Mycobacterium leprae are the major stimulants of the cell mediated immunity, ${ }^{8}$ and CWPs of $M$ tuberculosis are known to play a part in establishing protective immunity. ${ }^{9}$ The $M$ protein of the group A streptococcal CWPs is a major virulence factor with superantigenic activity. ${ }^{10}$ Group A streptococcal $M$ protein has shared epitopes with the articular cartilage and synovium, ${ }^{11}$ and systemic administration of streptococcal cell wall induces a chronic, destructive arthritis in susceptible rat strains. ${ }^{12}$

The bacterial cell wall PG-PS complex can initiate and sustain a chronic destructive inflammation. ${ }^{13}$ PG-PS isolated from human intestinal flora bacteria can induce chronic arthritis in rats. ${ }^{14}{ }^{15}$ The arthritogenic ability of cell wall constituents is dependent on resistance to biodegradation and consequent persistence in the tissues. ${ }^{13}$ The PS moiety 
covalently bound to PG is essential for the PG-PS complexes to persist and induce chronic inflammation. Streptococcal PG-PS did not sustain chronic arthritis when the PS moiety was removed, ${ }^{16}$ and PS alone induced only mild oedema in the joints. ${ }^{17}$ Another structural basis for streptococcal arthritogenicity is the presence of an acetyl moiety at the C-6 hydroxyl group of $\mathrm{N}$-acetylmuramyl residues of PG, producing the corresponding 2,6diacetylmuramyl PG (O-acetylated $\mathrm{PG}) .{ }^{18}$ Gonococcal O-acetylated PG is more resistant to enzyme degradation than non- $O$-acetylated $\mathrm{PG},{ }^{19}$ and subsequently persists in the tissues longer, leading to chronic arthritis. ${ }^{20} \mathrm{De}-\mathrm{O}$ acylated group A streptococcal PG-PS induced less severe chronic arthritis than native PGPS. ${ }^{21}$ In this study we aimed at defining the arthritogenic component(s) of the $E$ aerofaciens cell wall to determine whether the same requirements are valid for a representative of the normal human gut flora and a pathogenic Streptococcus.

\section{Methods \\ BACTERIA \\ Eubacterium aerofaciens ATCC 25986 was obtained from the Culture Collection, Univer- sity of Gothenburg, Sweden, with a nomination CCUG 28087. E limosum ATCC 8486 was purchased from the American Type Culture Collection, Rockville, MD, USA. Both strains were grown overnight under strictly anaerobic conditions at $37^{\circ} \mathrm{C}$ in $\mathrm{BBL}$ Schaedler Broth (Becton Dickinson Microbiology Systems, Cockeysville, MD, USA) to the late logarith- mic phase. They were characterised by $16 \mathrm{~S}$ rDNA sequence analysis as described by Jalava et al. $^{22}$}

CRUDE CELL WALL PREPARATION

Bacterial crude cell walls were isolated as described previously. ${ }^{23}$ Briefly, the cells were broken with glass beads (diameter 0.45-0.50 $\mathrm{mm}$ ) in an MSK cell homogeniser (B Braun Melsungen AG, Melsungen, Germany). The cell walls were collected by centrifugation, treated with deoxyribonuclease I $(1 \mathrm{mg} / \mathrm{g}$ wet weight), ribonuclease A (10 mg/g wet weight), and trypsin (20 mg/g wet weight), washed, and sonicated in an ice bath for 75 minutes (Branson Sonifier, Smith Kline Co, Danbury, Conn., USA). The sonicated cell wall suspension was centrifuged at $10000 \times \mathrm{g}, 4^{\circ} \mathrm{C}$, for 20 minutes. The supernatant was centrifuged by ultracentrifugation (Sorvall Ultracentrifuge OTD65B, rotor $60 \mathrm{Ti}, \mathrm{Du}$ Pont Co, Wilmington, USA) at $100000 \times g, 4^{\circ} \mathrm{C}$, for 60 minutes. The pellet containing the cell wall was suspended in water. For chemical analysis the cell walls were dialysed in membrane (MWCO 3500, Spectrum, CA, USA) against distilled water. For IP injection into rats the cell wall suspension was sterilised by heating at $90^{\circ} \mathrm{C}$ for 30 minutes. $^{24}$ The sterility was checked by cultures on agar plates at $37^{\circ} \mathrm{C}$ and at room temperature under aerobic and anaerobic conditions; no bacterial growth was detected after two days of culture. The endotoxin tests by E-TOXATE (Sigma
Chemical Co, MO, USA) were also found to be negative. These procedures were applied for all cell wall preparations used.

PG-PS POLYMERS

To obtain PG-PS polymers, the CWPs were removed; the crude cell walls were treated with proteolytic enzymes, protease (Subtilisin Carlsberg, $5 \mathrm{mg} / \mathrm{g}$ wet weight), proteinase $\mathrm{K}$ ( 2 $\mathrm{mg} / \mathrm{g}$ wet weight), pepsin ( $20 \mathrm{mg} / \mathrm{g}$ wet weight), and papain ( $5 \mathrm{mg} / \mathrm{g}$ wet weight). All enzymes were purchased from Sigma Chemical Co, MO, USA. After lyophilisation the cell walls were extracted with chloroform-methanol (2:1 $\mathrm{vol} / \mathrm{vol}, 40 \mathrm{mg} / \mathrm{ml}$ ) at room temperature for four hours to remove lipoteichoic acid or glycosyl glycerides. ${ }^{16}$ After washing once with water and dialysis against distilled water, the cell walls were treated by $8 \mathrm{M}$ lithium chloride at room temperature for one hour to remove any non-covalently bound CWPs. ${ }^{25}$ The cell walls were collected by ultracentrifugation and washed twice with distilled water. They were extracted with $0.1 \mathrm{M}$ EDTA at room temperature for one hour to remove any divalent cation stabilised oligomeric proteins. ${ }^{26}$ After ultracentrifugation and washing twice with distilled water the cell walls were suspended in acetone at room temperature for one hour and further mixed at $4^{\circ} \mathrm{C}$ for 30 hours to remove possible contaminating proteins and endotoxin. ${ }^{27}{ }^{28}$ The cell walls were collected by ultracentrifugation, washed three times with distilled water, and dialysed against distilled water. The preparations thus obtained are PG-PS complexes as shown by gas chromatography-mass spectrometry (GC-MS) analysis.

PS AND SOLUBLE PG POLYMERS

PG and PS polymers were isolated from $E$ aerofaciens ATCC 25986 as described previously for Lactobacillus. ${ }^{29}$ Briefly, the lyophilised cell walls were extracted with $10 \%$ trichloroacetic acid at $60^{\circ} \mathrm{C}$ for four hours. The suspension was centrifuged at $38800 \times g$ at $4^{\circ} \mathrm{C}$ for 30 minutes and washed once with distilled water. The supernatant contained the PS fraction, and the pellet the PG fraction. The soluble PG was obtained as described previously. ${ }^{24}$ The PG fraction was lyophilised and suspended in water at $10 \mathrm{mg} / \mathrm{ml}$ and sonicated (Branson Sonifier) for 180 minutes $(18 \times 10$-minute cycles with breaks for cooling between the cycles) in an ice bath. The remaining insoluble PG fraction was removed by centrifugation at $10000 \times g$ at $4^{\circ} \mathrm{C}$ for 30 minutes. The supernatant (soluble PG fraction) was collected and dialysed against distilled water for 48 hours.

DE-O-ACYLATION OF CELL WALL

The treatment of the cell walls for de-Oacylation was done as described previously. ${ }^{21}$ Briefly, the cell walls were lyophilised, suspended in $0.05 \mathrm{M}$ sodium hydroxide at $37^{\circ} \mathrm{C}$ for four hours. After washing three times with distilled water, the cell walls were fragmented by sonication and subsequently separated by differential centrifugation as described above for the cell wall preparation. 
Table 1 Gas chromatography-mass spectrometry analysis of the cell wall preparations

\begin{tabular}{|c|c|c|c|c|c|c|}
\hline \multirow[b]{2}{*}{ Component } & \multicolumn{4}{|l|}{$E$ aerofaciens } & \multicolumn{2}{|l|}{ E limosum } \\
\hline & Crude cell wall & $P G-P S^{\star}$ & $P G$ & $P S$ & Crude cell wall & $P G-P S$ \\
\hline \multicolumn{7}{|l|}{ Carbohydrates } \\
\hline \multicolumn{7}{|l|}{ Sugars } \\
\hline Rhamnose & 18.5 & 18.0 & - & 30.3 & 20.4 & 29.0 \\
\hline Glucose + galactose & 30.9 & 27.0 & 1.0 & 50.1 & 14.9 & 3.8 \\
\hline \multicolumn{7}{|l|}{ Amino sugars } \\
\hline$N$-Acetylmuramic acid & 1.9 & 9.2 & 11.5 & 0.6 & 2.9 & 13.1 \\
\hline$N$-Acetylglucosamine & 7.6 & 14.3 & 9.1 & 11.1 & 2.1 & 7.2 \\
\hline$N$-Acetylgalactosamine & - & - & - & - & 3.9 & 9.0 \\
\hline \multicolumn{7}{|l|}{ Amino acids } \\
\hline Alanine & 5.0 & 4.9 & 20.4 & 0.3 & 3.6 & 3.5 \\
\hline Glutamic acid/glutamine & 6.0 & 8.1 & 32.8 & 1.0 & 8.0 & 10.1 \\
\hline Lysine & 9.7 & 6.4 & 24.2 & 0.3 & 9.0 & 4.6 \\
\hline Aspartic acid/asparagine & 4.8 & 6.9 & 17.0 & 0.4 & 2.7 & 0.3 \\
\hline Ornithine & $<0.1$ & $<0.1$ & 0.3 & 0.1 & 12.1 & 18.7 \\
\hline Serine & $<0.1$ & - & 0.1 & $<0.1$ & 3.4 & 9.6 \\
\hline Leucine & 0.4 & $<0.1$ & 0.4 & $<0.1$ & 2.5 & $<0.1$ \\
\hline Isoleucine & 0.4 & $<0.1$ & 0.7 & - & 2.0 & 0.2 \\
\hline Phenylalanine & 0.2 & $<0.1$ & 0.7 & $<0.1$ & 1.4 & $<0.1$ \\
\hline Proline & 0.3 & $<0.1$ & 0.5 & 0.2 & 1.4 & $<0.1$ \\
\hline Tyrosine & 0.3 & $<0.1$ & 0.3 & $<0.1$ & 1.0 & $<0.1$ \\
\hline Valine & 0.4 & - & - & - & 1.6 & $<0.1$ \\
\hline
\end{tabular}

Each component is expressed as a percentage of the dry weight of cell wall. Figures in bold indicate PG amino sugars and amino acids. Norleucine, methionine, tryptophan were applied as internal standards for amino acid analysis. Cystine, glycine, threonine, diaminopimelic acid, cysteine, arginine, and histidine were not found.

${ }^{\star}$ PG-PS = peptidoglycan-polysaccharide.
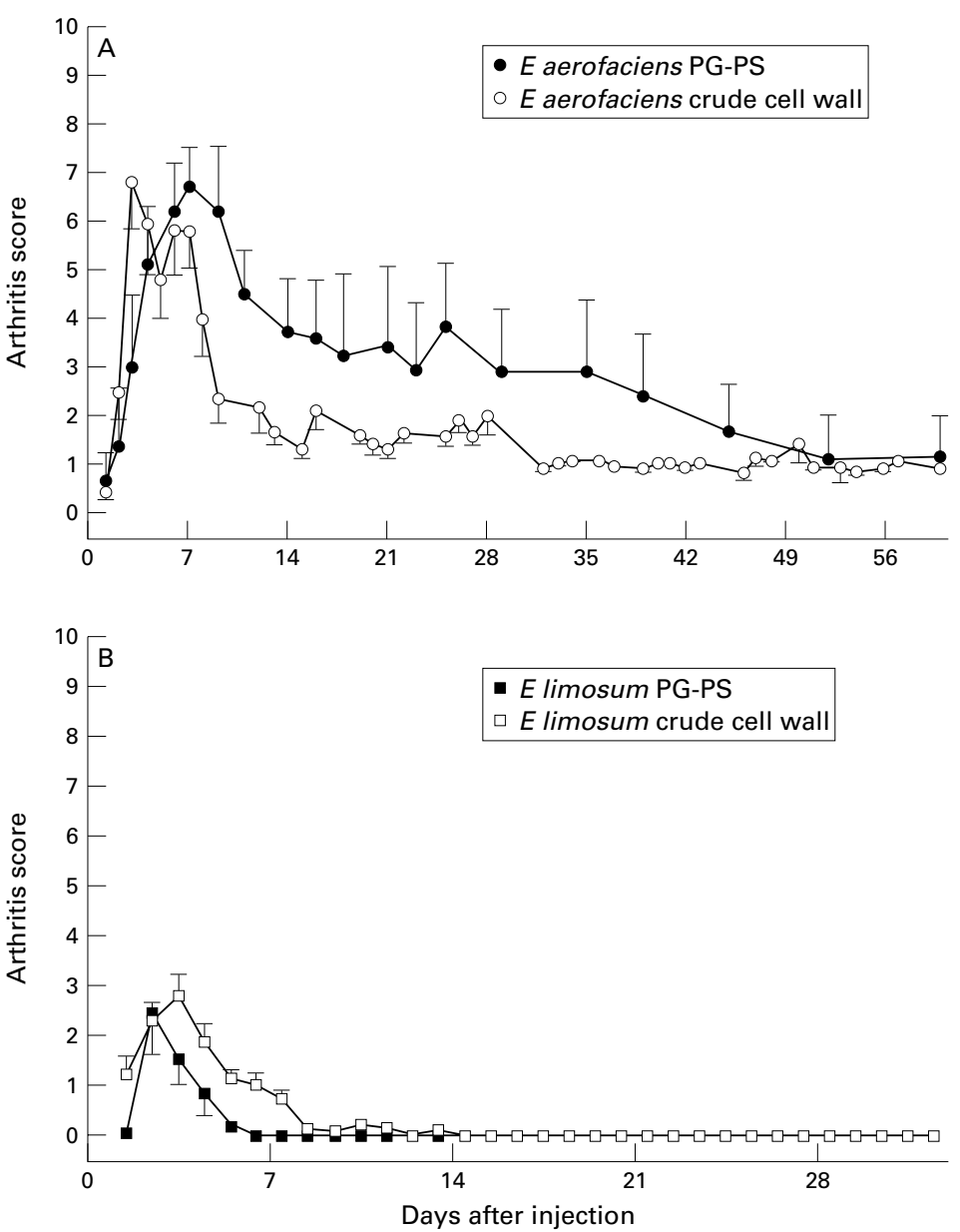

Figure 2 (A) A single intraperitoneal (IP) injection of $E$ aerofaciens peptidoglycan-polysaccharide (PG-PS; $150 \mu \mathrm{g} / \mathrm{g}$ body weight of rat) induced a more severe chronic arthritis than that induced with a crude cell wall (140 $\mu \mathrm{g} / \mathrm{g}$ body weight of rat)

( $p<0.02$ by non-parametric Mann-Whitney $U$ test). Each black symbol represents a mean (SEM) of six rats. Each white symbol represents a mean (SEM) of 11 rats. (B) Rats injected with E limosum PG-PS (200 $\mu \mathrm{g} / \mathrm{g}$ body weight of rat) IP or with the crude cell wall $(200 \mu \mathrm{g} / \mathrm{g}$ body weight of rat) developed only mild acute arthritis. Each black symbol represents a mean (SEM) of eight rats. Each white symbol represents a mean (SEM) of six to 12 rats.
GAS CHROMATOGRAPHY-MASS SPECTROMETRY (GC-MS)

The chemical composition of the cell wall preparations was analysed by GC-MS as described previously. ${ }^{30}$ The derivatised molecules were ionised by the electron impact method and analysed in the selected ion monitoring mode using single positive ions at a mass to charge ratio $(\mathrm{m} / \mathrm{z})$. Sugars were analysed as alditol acetate derivatives with the same ions as monitored by Gilbart et $a{ }^{30}{ }^{30}$ except m/z 289 for rhamnose. Fucose was used as internal standard for rhamnose, allose for glucose/galactose, and $N$-methyl-D-glucamine for muramic acid. Amino acids were analysed as butyl heptafluorobutyl derivatives with the same ions as used by Gilbart et al. ${ }^{30}$ L-Norleucine was used as internal standard for glycine, serine, alanine, leucine, cysteine, threonine, isoleucine, and valine; L-methionine for phenylalanine, glutamic acid/glutamine, proline, ornithine, lysine, aspartic acid/asparagine, and tyrosine; L-tryptophan for cystine, diaminopimelic acid, histidine, and arginine. One microlitre of the derivative was injected in the pulsed splitless mode and analysed by a gas chromatograph (model HP 5890A; Hewlett-Packard, Wilmington, DE) equipped with a fused silica capillary column (SE-54; Nordian Instruments, Helsinki) and coupled directly with a TRIO-1 mass spectrometer (VG Instruments, Manchester, UK). The oven temperature for sugars was started at $50^{\circ} \mathrm{C}$, programmed to $270^{\circ} \mathrm{C}$ at a rate of $10^{\circ} \mathrm{C} / \mathrm{min}$, and held for one minute; finally, the oven was heated to $290^{\circ} \mathrm{C}$ for five minutes. For amino acids the oven temperature was started at $85^{\circ} \mathrm{C}$, programmed to $280^{\circ} \mathrm{C}$ at a rate of $10^{\circ} \mathrm{C} / \mathrm{min}$, and held for one minute; finally, the oven was heated to $290^{\circ} \mathrm{C}$ for five minutes.

ANIMALS AND INDUCTION OF ARTHRITIS

All the animal experiments were done in concordance with the national and international 

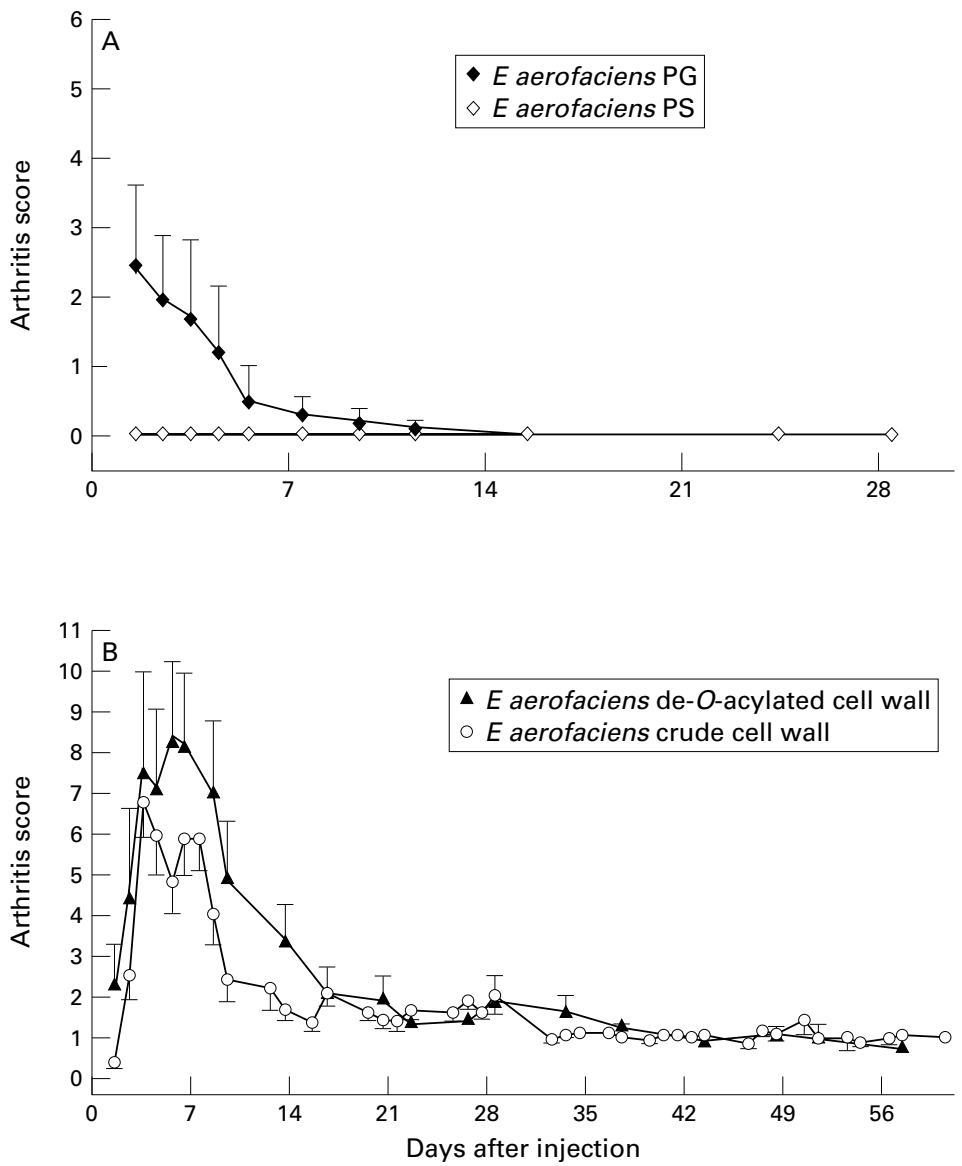

Figure 3 (A) Rats injected with $E$ aerofaciens peptidoglycan ( $P G ; 33 \mu \mathrm{g} / \mathrm{g}$ body weight of rat) intraperitoneally (IP) deprived of polysaccharide (PS), developed only acute arthritis. Rats injected with $E$ aerofaciens PS alone $(122 \mu \mathrm{g} / \mathrm{g}$ body weight of rat) did not develop any arthritis. Each symbol represents a mean (SEM) of five rats. (B) Rats injected with $E$ aerofaciens de-O-acylated cell wall $(140 \mu \mathrm{g} / \mathrm{g}$ body weight of rat) IP developed arthritis similar to that seen after injection of the crude cell wall (140 $\mu \mathrm{g} / \mathrm{g}$ body weight of rat). Each black symbol represents a mean (SEM) of six rats. Each white symbol represents a mean (SEM) of 11 rats.
SENSITIVITY TO LYSOZYME

The sensitivity of different cell wall preparations to lysozyme was tested as described previously. ${ }^{21}$ Suspensions of cell wall preparations $(4 \mathrm{mg} / \mathrm{ml})$ in $0.1 \mathrm{M}$ sodium acetate buffer $(\mathrm{pH}$ 5.0) were incubated with lysozyme (400 $\mu \mathrm{g} / \mathrm{ml}$ ) at $37^{\circ} \mathrm{C}$. The optical density of the suspension was measured at wavelength $560 \mathrm{~nm}$ after five and 24 hours' incubation.

STATISTICAL ANALYSIS

Differences of arthritis development between the experimental groups were analysed with the non-parametric Mann-Whitney U test. Differences were considered significant at $\mathrm{p}<0.05$.

\section{Results}

IDENTIFICATION OF BACTERIA

The gene coding for $16 \mathrm{~S}$ ribosomal RNA is generally used to identify bacterial strains. To confirm the identity of the bacterial strains used in this study the genes coding for this region were partially sequenced $(320-452$ base pairs). Both for $E$ aerofaciens and for $E$ limosum, a $100 \%$ identity with respective sequences in the GenBank data base was confirmed. In addition, a $72.6 \%$ identity between the strains of $E$ aerofaciens and $E$ limosum was obtained.

ANALYSIS OF CELL WALL PREPARATION BY GC-MS All bacterial cell wall preparations were analysed by GC-MS before injection into the rats (table 1). The total amount of protein amino acids is $2.2 \%$ in the $E$ aerofaciens crude cell wall, and less than $0.6 \%$ in its PG-PS polymer, in which the amount of individual protein amino acids is less than $0.1 \%$. The amount of protein amino acids is $12.6 \%$ in the E limosum crude cell wall, and less than $0.7 \%$ in its PG-PS polymer. Both bacterial PSs contain rhamnose and glucose/ galactose. $E$ aerofaciens PS also contains $\mathrm{N}$-acetylglucosamine. $\mathrm{N}$-Acetylgalactosamine is present in the Elimosum cell wall and missing in the $E$ aerofaciens cell wall. PG of both cell walls contains the amino sugars $N$-acetylmuramic acid and $\mathrm{N}$-acetylglucosamine. Arthritogenic $E$ aerofaciens has four PG amino acids: alanine, glutamic acid, lysine, and aspartic acid. Nonarthritogenic $E$ limosum cell wall has five PG amino acids: alanine, glutamic acid, lysine, ornithine, and serine (table 1). These findings are in concert with the previously reported PG types$\mathrm{A} 4 \alpha$ for $E$ aerofaciens and B2 $\alpha$ for $E$ limosum. ${ }^{23}$

\section{INDUCTION OF ARTHRITIS}

For induction of arthritis a single IP injection of the cell wall components was applied. $E$ limosum PG-PS appeared non-arthritogenic, similar to the crude cell wall of $E$ limosum (fig 2B). A high dose $(200 \mu \mathrm{g} / \mathrm{g}$ body weight $)$ of PG-PS isolated from the arthritogenic $E$ aerofaciens crude cell wall was toxic, leading to death within three days (data not shown here), probably owing to the high PG content. When a lower dose $(150 \mu \mathrm{g} / \mathrm{g}$ body weight of rat) was used, E aerofaciens PG-PS caused a significantly more severe chronic arthritis than the equivalent dose of the crude cell wall (fig 2A), suggesting that the PG-PS complex possesses were killed under anaesthesia by Metofane (Pitman-Moore, Inc, Washington Crossing, NJ, USA). 
Table 2 Degradation of bacterial cell wall preparations by lysozyme

\begin{tabular}{|c|c|c|c|c|}
\hline \multirow[b]{2}{*}{ Substrate } & \multicolumn{2}{|c|}{ Lysozyme $5 \mathrm{~h}$} & \multicolumn{2}{|c|}{ Lysozyme $24 h$} \\
\hline & - & + & - & + \\
\hline \multicolumn{5}{|l|}{$E$ aerofaciens } \\
\hline Crude cell wall & 2.0 & 15.6 & 1.9 & 20.7 \\
\hline De- $O$-acylated & 5.3 & 31.0 & 7.5 & 30.7 \\
\hline PG-PS & 1.9 & 15.8 & 3.9 & 23.5 \\
\hline PG & 0 & 75.9 & 0 & 79.3 \\
\hline \multicolumn{5}{|l|}{ E limosum } \\
\hline Crude cell wall & 0.7 & 24.4 & 4.7 & 58.5 \\
\hline
\end{tabular}

Results are given as the percentage decrease of the $\mathrm{OD}_{560}$ after five hours and 24 hours' incubation with or without lysozyme, compared with the $\mathrm{OD}_{560}$ at time 0 . Mean values from triplicate experiments are given.

the structure decisive for arthritogenicity. However, after the PS moiety was removed, the PG alone induced only acute arthritis. Likewise, PS alone did not induce any arthritis (fig $3 \mathrm{~A})$. Further, attempts to de- $O$-acetylate the $E$ aerofaciens cell wall did not affect its arthritogenicity (fig 3B). None of the rats injected with PBS alone developed arthritis.

DEGRADATION OF BACTERIAL CELL WALL

PREPARATIONS BY LYSOZYME

$E$ aerofaciens crude cell wall was found to be resistant to degradation by lysozyme; only $20.7 \%$ was degraded after 24 hours' treatment with this enzyme (table 2). In contrast, $E$ limosum crude cell wall was susceptible to lysozyme, with $58.5 \%$ degradation after 24 hours. De-O-acetylation of $E$ aerofaciens cell wall did not affect its susceptibility to lysozyme. $E$ aerofaciens PG-PS showed the same degree of lysozyme resistance as the crude cell wall, whereas PG alone (after removal of PS) was rapidly degraded by lysozyme; $75.9 \%$ was already degraded after five hours (table 2).

\section{Discussion}

It has been shown that synovial tissue of patients with RA may harbour traces of bacterial $P G .^{32}$ The results presented in this paper, obtained with a normal bacterial habitant $(E$ aerofaciens) of the human intestine, indicate that the PG moiety of the bacterial cell wall contains a structure decisive for induction of chronic arthritis in rats. They also show that the PG-PS complex is necessary for the arthritis induction; the PS moiety most probably protects PG from enzyme digestion through steric hindrance, allowing prolonged tissue persistence and leading to the chronic synovial inflammation. Similar conclusions have previously been reached in studies on streptococcal cell wall arthritis. ${ }^{16} \mathrm{Up}$ to this point, our observations indicate that the same principles apply for the chemical structure, determining arthritogenicity here also, independently of the bacterial species used. However, in contrast with the streptococcal cell wall, in which the $\mathrm{O}$-acetylation is known to be associated with the arthritogenicity and resistance against biodegradation, ${ }^{21} \mathrm{O}$-acetylation does not seem to be a prerequisite for the arthritogenicity or biodegradation of the $E$ aerofaciens cell wall. Our findings suggest that $O$-acetylation does not occur in $E$ aerofaciens cell wall or only occurs to a small degree. The gonococcal cell wall seems to resemble the streptococcal cell wall in this respect because $O$-acetylation is required for its arthritogenicity. ${ }^{19}{ }^{20}$

Lysozyme susceptibility is usually thought to be associated with arthritogenicity of the cell wall. Almost all bacterial strains studied for their ability to induce cell wall arthritis have been found to be lysozyme resistant; this includes species of Lactobacillus, Streptococcus, Bifidobacterium, and Eubacterium. ${ }^{33}$ The only exception is the $E$ limosum cell wall, which is non-arthritogenic and which has been reported to be lysozyme resistant. ${ }^{3}$ However, our results obtained by using the same strain of $E$ limosum indicate both non-arthritogenicity and lysozyme sensitivity (table 2). Furthermore, because PG is degraded in vivo by other enzymes also (for example, $\mathrm{N}$-acetylmuramyl-L-alanine amidase, $N$-acetylglucosaminidase, and others), ${ }^{1934} 35$ it is unlikely that lysozyme resistance alone would be a decisive requirement for the ability of a cell wall to induce chronic arthritis.

It has so far remained undetermined whether CWPs attached to PG-PS contribute or are required for induction of chronic arthritis. Our results indicate that their presence is not necessary for arthritis induction. Removal of CWPs by proteolytic enzymes resulted in PG-PS which induced an even more severe chronic arthritis than that seen after injection of an equivalent amount of the crude cell wall (fig 2A). These findings parallel those showing that genetic mutation of the streptococcal $M$ protein attached to PG does not change arthritogenicity of the cell wall. ${ }^{36}$ Otherwise, results from GS-MS analyses (table 1) show very little, if any, further information about chemical or structural requirements for arthritogenicity. For instance, the presence of rhamnose does not correlate with this ability, even though such a correlation has previously been suggested. ${ }^{37}$

In a previous study on four Eubacterium strains it was shown that the chemical structure of PG present in the bacterial cell walls is decisive in determining arthritogenicity/nonarthritogenicity. ${ }^{23}$ The present results, based on characterisation of PG-PS complexes, further strengthen that conclusion by indicating that the source of a cell wall plays no part in the chemical or structural requirements of PG arthritogenicity; it does not matter whether the cell wall is isolated from a normal habitant of the human intestine or from a pathogenic strain of Streptococcus. The structure of PG is decisive. Studies with other bacterial speciesfor example, with Clostridia and Bifidobacteria, are needed to elucidate further the detailed structural determinants of the PG arthritogenicity.

We thank Leena Kivistö, Marja-Riitta Teräsjärvi, Karolina Karlson, and Heli Niittymäki for excellent technical assistance, Jari Jalava for $16 \mathrm{~S}$ rDNA sequence analysis, and Yong Zhang for help in evaluating the arthritis.

This work was supported by EVO of Turku University Central Hospital.

1 Eerola E, Möttönen T, Hannonen P, Luukkainen R, Kantola $\mathrm{I}$, Vuori K, et al. Intestinal flora in early rheumatoid arthritis. Br J Rheumatol 1994;33:1030-8. 
2 Peltonen R, Nenonen M, Helve T, Hanninen O, Toivanen P, Eerola E. Faecal microbial flora and disease activity in rheumatoid arthritis during a vegan diet. $\mathrm{Br}$ J Rheumatol 1997;36:64-8.

3 Severijnen AJ, van Kleef R, Hazenberg MP, van de Merwe JP. Chronic arthritis induced in rats by cell wall fragments of Eubacterium species from the human intestinal flora. Infect Immun 1990;58:523-8.

4 Simelyte E, Rimpiläinen M, Rantakokko K, Lehtonen L, Zhang X, Aho $\mathrm{H}$, et al. Tissue distribution and persistence of arthritogenic and nonarthritogenic Eubacterium cell walls. Clin Exp Rheumatol 1999;17:281-8.

5 Pancholi V, Fischetti VA. Isolation and characterization of the cell-associated region of group A streptococcal M6 protein. J Bacteriol 1988;170:2618-24.

6 Ton That H, Faull KF, Schneewind O. Anchor structure of staphylococcal surface proteins. A branched peptide that links the carboxyl terminus of proteins to the cell wall. J links the carboxyl terminus of prot
Biol Chem 1997;272:22285-92.

7 Foster TJ, McDevitt D. Surface-associated proteins of Staphylococcus aureus: their possible roles in virulence. Staphylococcus aureus: their possible roles

8 Melancon Kaplan J, Hunter SW, McNeil M, Stewart C, Modlin RL, Rea TH, et al. Immunological significance of Mycobacterium leprae cell walls. Proc Natl Acad Sci USA 1988;85:1917-21.

9 Barnes PF, Mehra V, Hirschfield GR, Fong SJ, Abou Zeid C, Rook GA, et al. Characterization of T cell antigens associated with the cell wall protein-peptidoglycan complex of Mycobacterium tuberculosis. J Immunol 1989;143:265662 .

10 Tomai M, Kotb M, Majumdar G, Beachey EH. Superantigenicity of streptococcal M protein. J Exp Med 1990;172: 359-62.

11 Baird RW, Bronze MS, Kraus W, Hill HR, Veasey LG, Dale JB. Epitopes of group A streptococcal M protein shared with antigens of articular cartilage and synovium. J Immunol 1991;146:3132-7.

12 Cromartie WJ, Craddock JG, Schwab JH, Anderle SK, Yang $\mathrm{CH}$. Arthritis in rats after systemic injection of streptococ$\mathrm{CH}$. Arthritis in rats after systemic injection of strepto

13 Schwab JH. Phlogistic properties of peptidoglycanpolysaccharide polymers from cell walls of pathogenic and normal-flora bacteria which colonize humans. Infect Immun 1993;61:4535-9.

14 Stimpson SA, Brown RR, Anderle SK, Klapper DG, Clark RL, Cromartie WJ, et al. Arthropathic properties of cell wall polymers from normal flora bacteria. Infect Immun 1986;51:240-9.

15 Severijnen AJ, van Kleef R, Hazenberg MP, van de Merwe JP. Cell wall fragments from major residents of the human intestinal flora induce chronic arthritis in rats. J Rheumatol 1989;16:1061-8.

16 Fox A, Brown RR, Anderle SK, Chetty C, Cromartie WJ, Gooder $\mathrm{H}$, et al. Arthropathic properties related to the molecular weight of peptidoglycan-polysaccharide polymers of streptococcal cell walls. Infect Immun 1982;35: mers of 10 .

17 Chetty C, Brown RR, Schwab JH. Edema-producing activity of group A streptococcal polysaccharide and its possible role in the pathogenesis of cell wall-induced polyarthritis. J Exp Med 1983;157:1089-100.

18 Clarke AJ, Dupont C. O-Acetylated peptidoglycan: its occurrence, pathobiological significance, and biosynthesis. Can J Microbiol 1991;38:85-91

19 Rosenthal RS, Folkening WJ, Miller DR, Swim SC. Resistance of O-acetylated gonococcal peptidoglycan to human peptidoglycan-degrading enzymes. Infect Immun 1983;40: 903-11.

20 Fleming TJ, Wallsmith DE, Rosenthal RS. Arthropathic properties of gonococcal peptidoglycan fragments: implications for the pathogenesis of disseminated gonococcal disease. Infect Immun 1986:52:600-8.
21 Stimpson SA, Lerch RA, Cleland DR, Yarnall DP, Clark RL, Cromartie WJ, et al. Effect of acetylation on arthropathic activity of group A streptococcal peptidoglycan-polysaccharide fragments. Infect Immun 1987;55:16-23.

22 Jalava J, Mäntymaa ML, Ekblad U, Toivanen P, Skurnik M, Lassila $\mathrm{O}$, et al. Bacterial 16S rDNA polymerase chain reaction in the detection of intra-amniotic infection. $\mathrm{Br} \mathrm{J}$ Obstet Gynaecol 1996;103:664-9.

23 Zhang X, Rimpiläinen M, Simelyte E, Toivanen P. What determines arthritogenicity of bacterial cell wall? A study on Eubacterium cell wall-induced arthritis. Rheumatology $2000 ; 39 \cdot 274-82$.

24 Rosenthal RS, Dziarski R. Isolation of peptidoglycan and soluble peptidoglycan fragments. Methods Enzymol 1994; 235:253-85

25 Doyle RJ, Streips UN, Fan VS, Brown WC, Mobley H, Mansfield JM. Cell wall protein in Bacillus subtilis. J Bacteriol 1977;129:547-9.

26 de Maagd RA, Wienties FB, Lugtenberg BJ. Evidence for divalent cation $(\mathrm{Ca} 2+)$-stabilized oligomeric proteins and covalently bound protein-peptidoglycan complexes in the outer membrane of Rhizobium leguminosarum. J Bacteriol 1989;171:3989-95.

27 Hill SA, Judd RC. Identification and characterization of peptidoglycan-associated proteins in Neisseria gonorrhoeae. Infect Immun 1989;57:3612-18

28 Majcherczyk PA, Langen H, Heumann D, Fountoulakis M, Glauser MP, Moreillon P. Digestion of Streptococcus pneumoniae cell walls with its major peptidoglycan hydrolase releases branched stem peptides carrying proinflammatory activity. J Biol Chem 1999;274:12537-43.

29 Sato K, Saito H, Tomioka H, Yokokura T. Enhancement of host resistance against listeria infection by Lactobacillus casei: efficacy of cell wall preparation of Lactobacillus casei. Microbiol Immunol 1988;32:1189-200.

30 Gilbart J, Harrison J, Parks C, Fox A. Analysis of the amino acid and sugar composition of streptococcal cell walls by gas chromatography-mass spectrometry. J Chromatogr gas chromatograp

31 Zhang Y, Gripenberg Lerche C, Soderstrom KO, Toivanen A, Toivanen P. Antibiotic prophylaxis and treatment of reactive arthritis. Lessons from an animal model. Arthritis Rheum 1996;39:1238-43.

32 van der Heijden IM, Wilbrink B, Tchetverikov I, Schrijver IA, Schouls LM, Hasenberg MP, et al. Presence of bacterial DNA and bacterial peptidoglycans in joints of patients with Deumatoid arthritis and other arthritides. Arthritis Rheum 2000;43:593-8.

33 Šimelyte E, Rimpiläinen M, Lehtonen L, Zhang X, Toivanen P. Bacterial cell wall-induced arthritis: chemical Toivanen P. Bacterial cell wall-induced arthritis: chemical
composition and tissue distribution of four Lactobacillus composition and tissue distribution of four
strains. Infect Immun 2000;68:3535-40.

34 Hoijer MA, Melief MJ, Calafat J, Roos D, van den Beemd $\mathrm{RW}$, van Dongen JJ, et al. Expression and intracellular localization of the human N-acetylmuramyl-L-alanine amidase, a bacterial cell wall-degrading enzyme. Blood 1997;90:1246-54

35 Striker R, Kline ME, Haak RA, Rest RF, Rosenthal RS. Degradation of gonococcal peptidoglycan by granule extract from human neutrophils: demonstration of N-acetylglucosaminidase activity that utilizes peptidoglycan substrates. Infect Immun 1987;55:2579-84.

36 DeJoy SQ, Ferguson Chanowitz KM, Sapp TM, Oronsky AL, Lapierre LA, Zabriskie JB, et al. M protein deficient streptococcal cell walls can induce acute and chronic arthritis rats. Cell Immunol 1990;125:526-34.

37 Lehman TJ, Allen JB, Plotz PH, Wilder RL. Bacterial cell wall composition, lysozyme resistance, and the induction of chronic arthritis in rats. Rheumatol Int 1985;5:163-7. 